\title{
Reduction of the time required for POH of Diesel Locomotives using Unit Replacement
}

\author{
Saurabh Singh Chandrawat ${ }^{1}$, Doulat T. Gianchandani ${ }^{2}$ \\ ${ }^{I}$ (HOD \& Assistant Professor Department of Mechanical Engineering Mewar University Chittorgarh India) \\ ${ }^{2}$ (M. Tech IV semester Department of Mechanical Engineering Mewar University Chittorgarh India)
}

\begin{abstract}
To ensure maximum availability and optimum utilization of the locomotives, scheduled preventive maintenance is carried out at specified intervals. Any excess time taken, directly affects the availability of locomotives for rail services. In this paper a case study of implementation of the unit replacement method at Diesel POH shop Ajmer will be examined. In order to be able to conduct experiments historical data of POH cycle time for over one year were gathered to calculate current average cycle time for POH. 14 locos overhauled from $1^{\text {st }}$ January 2012 were selected for the case study. The unit replacement method was hypothetically applied in the engine section for these locos. The result was an average $\mathrm{POH}$ cycle time reduced from 31.07 days to 26.92 days. The result supported the hypothesis that "Time required for Periodic Overhauling of Diesel Locomotives can be reduced using Unit Replacement"
\end{abstract}

Key Words: Cycle time, Day, Locomotive (loco), Periodic Overhauling (POH), Unit,

\section{Introduction}

\subsection{Maintenance}

Maintenance is a process where equipment is kept in their original condition and that restores the ${ }_{21}$ roduction function after equipment and machinery have broken down in order to prevent further breakdowns. ${ }^{[1}$,

\subsection{Preventive maintenance}

Kelly and Harris (1978:6) define preventive maintenance as that operation which is carried out at predetermined intervals and intended to reduce the likelihood of the equipment's condition falling below a required level of acceptability. ${ }^{[3]}$

\subsection{Maintenance of rolling stock}

Rolling stock is the stock that rolls on the railway track. It includes locomotives, coaches, wagons, cranes for accident relief train etc.. The safety of Train operations is dependent on proper maintenance of tracks, rolling stock and other Railway assets. These are required to be maintained and replaced at constant intervals for smooth and safe train running. Hence, maintenance of Rolling Stock is of paramount importance for smooth, efficient and safe running of the whole railway system. Diesel locomotives are given running maintenance and periodic overhauls at prescribed intervals. Primarily maintenance sheds take care of the running maintenance this consists of attention to various components, topping of consumables, change of components if necessary and checking of safety fitting etc. ${ }^{[4]}$

Periodic Overhauling (POH)

The periodic overhauling (POH) of diesel locomotives is carried out in various workshops nominated for this purpose. Such overhauls consist of lifting, thorough examination of all parts and execution of such repairs as may be necessary. In locomotives there are major components, the whole power pack has to be brought down and a lot of repair work is required to be done on that. ${ }^{[4]}$

\subsection{Problem statement}

For every maintenance schedule, time is prescribed by the railways. Maintenance schedules are delayed when the components need additional repair.

The time prescribed for $\mathrm{POH}$ of diesel locomotive at Ajmer workshop is 25 days. It is observed that in most of the cases the $\mathrm{POH}$ maintenance schedule is not completed in the prescribed time. The average time taken for completing POH is between 30 to 31 days. The reasons causing delay in completion of schedule differs from loco to loco. 
The objective of this project is to study all the operations required for $\mathrm{POH}$ of diesel locomotives, find out reasons causing delay and suggest an improved method so that the required maintenance schedule can be completed within the time prescribed for that.

\subsection{Contributions}

If this work shows that using unit replacement method can provide a solution of the problem that the $\mathrm{POH}$ schedule of Diesel Locomotive may be completed in the prescribed time that is not obvious using any conventional method e.g. Working overtime or engaging extra manpower. It will support the argument that the reduction of the time required for $\mathrm{POH}$ of Diesel Locomotives is possible using unit replacement method.

\subsection{Case study methodology}

Prior to the beginning of this work a study of the entire operation at Diesel POH shop Ajmer was conducted to find out the reasons for the delay in $\mathrm{POH}$ maintenance cycle time. Various operations necessary to be carried out for $\mathrm{POH}$ were observed. The $\mathrm{POH}$ maintenance schedule is event oriented; the cycle time prescribed for POH of BG locos at Diesel Shop Ajmer is 25 days. Each section of Diesel shop is given a day on which the work related to that section should be completed. The counting of days starts from the date a loco is taken in hand for maintenance. Sundays and holidays are not counted. The engine section having maximum problems was selected for case study.

\section{The Hypothesis}

The hypothesis is "Time required for Periodic Overhauling of Diesel Locomotives can be reduced using Unit Replacement".

\subsection{What does Unit Replacement mean?}

The unit replacement method can be easily understood from the following example:

When one of the tires of a car gets punctured and there is no repair shop nearby, The punctured tire is immediately replaced by the Stepney (which is readily available). Efforts are made to get the original tire repaired as soon as the facility for that is available. The repaired tire will now become the Stepney.

Similarly if one set of each assembly is kept ready for replacement whenever the maintenance of the original assembly is delayed, the assembly available (unit) can be used in place of the original assembly and the delay in maintenance schedule can be avoided. The original assembly is made ready as soon as possible, the original assembly when ready will be known as a unit.

\subsection{Why to adopt Unit Replacement?}

$\mathrm{POH}$ of diesel loco includes a very large number of maintenance operations and deals with thousands of parts. Different problems are experienced when this maintenance schedule is carried out. Problems also vary from loco to loco. POH is not a simple assembly operation in which all the parts of an engine or machine are new and just needs assembly. In a manufacturing assembly line it is very easy to predict the quantity of all components required and the same can be made available in time.

In POH maintenance schedule, it is not possible to predict which component will need replacement. While doing POH of diesel locomotives it is possible that all the crankshafts of engines overhauled in a particular year (say 36 engines ) are in good condition and may be reused whereas, in the succeeding year the number of crank shafts rejected may be 10 or more.

The decision of rejecting a component can only be taken after cleaning, inspection and testing. The component that needs replacement may or may not be available at the point of time. Vital parts such as crankshafts cannot be stored in excess quantity to ensure minimum inventory. Some major components like engine blocks sometimes need excess repair which ultimately delays the assembly operation.

Most of the activities in $\mathrm{POH}$ maintenance schedule have got their preceding activity. An activity can't start until its preceding activity is over e.g. Assembly of bogie cannot start until the wheels and traction motors are received from their respective sections. It means bogie assembly will be delayed for the period through which either of the two units (wheels or traction motors) is delayed and the total project will be delayed for more or less the same period.

The above mentioned problems can be solved by replacing the unit when there is a delay due to any reason. The unit Replacement method may also overcome some other reasons causing delay, say more workers on leave due to a festive season, non availability of a critical component, delay in the arrival of a vital part, power failure for a specific period etc.

Unit Replacement is a unique solution to a variety of problems. 


\subsection{Significance of Unit Replacement method.}

The unit replacement method is significant when efforts are made to get the original assembly ready. In case the maintenance work of original assembly is not completed even when the reason causing delay is overcome, the unit will not be available for replacement. All possible efforts should be made to complete the maintenance work of the original assembly.

\subsection{When "Unit Replacement" will be ineffective?}

The Unit replacement method may be less effective when the problem in the same unit is experienced in two consecutive locos and the unit is not ready for replacement. This is similar to the case when an anther tire of a car punctures before the Stepney ready.

\section{Results And Discussion}

The time prescribed for $\mathrm{POH}$ of diesel loco is 25 days. Observing historical data it was noticed that the average cycle time for $\mathrm{POH}$ in previous year (2011-12) was 30.7 days.

\subsection{Excess time taken loco wise}

The locos taken in hand after $1^{\text {st }}$ January 2012 were selected for the case study. The excess time taken in the POH for these locos is calculated and recorded in Table1.

Table 1. Cycle time showing delays in scheduled maintenance

\begin{tabular}{|l|l|l|l|l|l|l|l|}
\hline S. No & $\begin{array}{l}\text { Loco } \\
\text { No. }\end{array}$ & $\begin{array}{l}\text { Arrived in } \\
\text { shop date }\end{array}$ & $\begin{array}{l}\text { Taken in hand } \\
\text { date }\end{array}$ & Dispatch Date & Stop days & $\begin{array}{l}\text { Working } \\
\text { days }\end{array}$ & $\begin{array}{l}\text { Days } \\
\text { Delayed }\end{array}$ \\
\hline $\mathrm{a}$ & $\mathrm{b}$ & $\mathrm{C}$ & \multicolumn{1}{c}{$\mathrm{d}$} & $\mathrm{e}$ & $\mathrm{f}$ & $\mathrm{g}$ & $\mathrm{h}=(\mathrm{g}-25)$ \\
\hline 1 & 14682 & 09.01 .12 & 10.01 .12 & 13.02 .12 & 36 & 29 & 4 \\
\hline 2 & 18708 & 14.01 .12 & 17.01 .12 & 17.02 .12 & 35 & 27 & 2 \\
\hline 3 & 17772 & 30.01 .12 & 31.01 .12 & 15.03 .12 & 46 & 37 & 12 \\
\hline 4 & 18659 & 31.01 .12 & 03.02 .12 & 17.03 .12 & 47 & 36 & 11 \\
\hline 5 & 13189 & 27.02 .12 & 28.02 .12 & 03.04 .12 & 37 & 30 & 5 \\
\hline 6 & 16104 & 17.03 .12 & 19.03 .12 & 19.04 .12 & 34 & 25 & 0 \\
\hline 7 & 18717 & 03.04 .12 & 04.04 .12 & 05.05 .12 & 33 & 26 & 1 \\
\hline 8 & 14880 & 07.04 .12 & 10.04 .12 & 11.05 .12 & 35 & 27 & 2 \\
\hline 9 & 14096 & 25.04 .12 & 26.04 .12 & 02.06 .12 & 39 & 33 & 8 \\
\hline 10 & 16135 & 03.05 .12 & 04.05 .12 & 08.06 .12 & 37 & 31 & 6 \\
\hline 11 & 16083 & 05.05 .12 & 10.05 .12 & 20.06 .12 & 47 & 36 & 11 \\
\hline 12 & 14903 & 24.05 .12 & 25.05 .12 & 05.07 .12 & 43 & 36 & 11 \\
\hline 13 & 16027 & 08.06 .12 & 11.06 .12 & 17.07 .12 & 40 & 32 & 7 \\
\hline 14 & 14121 & 20.06 .12 & 21.06 .12 & 25.07 .12 & 36 & 30 & 5 \\
\hline
\end{tabular}

\subsection{Delay on account of Engine Section}

The locos whose cycle time for $\mathrm{POH}$ is more than the prescribed time has experienced problems related to the engine section in most of the cases. The engine block assembly should be ready on the $18^{\text {th }}$ day in order to complete $\mathrm{POH}$ on the 25th day. Whenever there is a delay in assembly of engine block the cycle time for $\mathrm{POH}$ increases. Now we will look at the day on which the engine block assembly was ready for the same locos. The actual time taken loco wise is calculated and recorded in Table2.

Table 2. Cycle time showing delay in engine block assembly indicating reason

\begin{tabular}{|l|l|l|l|l|l|l|}
\hline $\begin{array}{l}\text { S. } \\
\text { No. }\end{array}$ & $\begin{array}{l}\text { Loco } \\
\text { No. }\end{array}$ & $\begin{array}{l}\text { Taken in } \\
\text { hand } \\
\text { date }\end{array}$ & $\begin{array}{l}\text { Block } \\
\text { ready on } \\
\text { Date }\end{array}$ & $\begin{array}{l}\text { Block } \\
\text { ready on } \\
\text { Day }\end{array}$ & $\begin{array}{l}\text { Block Delayed } \\
\text { Days }\end{array}$ & Reasons for delay \\
\cline { 1 - 6 } a & $\mathrm{b}$ & $\mathrm{c}$ & $\mathrm{d}$ & $\begin{array}{l}\text { e (working } \\
\text { days from } \\
\text { c to d) }\end{array}$ & $\mathrm{f}=(\mathrm{e}-18)$ & \\
\hline 1 & 14682 & 10.01 .12 & 07.02 .12 & 20 & 2 & Block \& crankshaft changed \\
\hline 2 & 18708 & 17.01 .12 & 13.02 .12 & 24 & 6 & Reason not specified \\
\hline 3 & 17772 & 31.01 .12 & 12.03 .12 & 33 & 15 & Cam eye bore needs repair \\
\hline 4 & 18659 & 03.02 .12 & 05.03 .12 & 26 & 8 & Block changed. \\
\hline 5 & 13189 & 28.02 .12 & 23.03 .12 & 20 & 2 & NIL \\
\hline 6 & 16104 & 19.0312 & 10.04 .12 & 17 & 0 & NIL \\
\hline
\end{tabular}


Reduction of the time required for POH of Diesel Locomotives using Unit Replacement

\begin{tabular}{|l|l|l|l|l|l|l|}
\hline 7 & 18717 & 04.04 .12 & 27.04 .12 & 19 & 1 & NIL \\
\hline 8 & 14880 & 10.04 .12 & 06.05 .12 & 23 & 5 & New crankshaft used \\
\hline 9 & 14096 & 26.04 .12 & 18.05 .12 & 20 & 2 & New block used. \\
\hline 10 & 16135 & 04.05 .12 & 05.06 .12 & 27 & 9 & Waiting for a block \\
\hline 11 & 16083 & 10.05 .12 & 14.06 .12 & 30 & 12 & New block \& crank used. \\
\hline 12 & 14903 & 25.05 .12 & 29.06 .12 & 31 & 13 & Block \& crank shaft rejected, \\
\hline 13 & 16027 & 11.06 .12 & 07.07 .12 & 24 & 6 & New block used. \\
\hline 14 & 14121 & 21.06 .12 & 18.07 .12 & 24 & 6 & Reclaimed block used. \\
\hline
\end{tabular}

\subsection{Impact of delay in engine block assembly on total cycle time}

The impact of the delay in the engine block assembly on total cycle time for $\mathrm{POH}$ is calculated for the same locos referred above. The comparison is shown in Table3. It is clear from Table 3 that: only one loco out of the 14 locos was ready in the prescribed time of 25 days, 8 locos delayed purely on account of the engine block assembly. Remaining five locos are also delayed on account engine block assembly. In addition to that some more causes of delay are there. This shows that whenever there is a delay in assembly of the engine block, the total maintenance schedule is delayed.

Table 3. Delay in engine block assembly v/s delay in total cycle time

\begin{tabular}{|c|c|c|c|c|c|c|c|}
\hline S.No & $\begin{array}{l}\text { Loco } \\
\text { No. }\end{array}$ & $\begin{array}{l}\text { Taken in } \\
\text { hand date }\end{array}$ & $\begin{array}{l}\text { Block ready } \\
\text { on Date }\end{array}$ & $\begin{array}{l}\text { Block } \\
\text { ready on } \\
\text { day }\end{array}$ & $\begin{array}{l}\text { Block } \\
\text { Delayed } \\
\text { by Days }\end{array}$ & $\begin{array}{l}\text { Days } \\
\text { Loco } \\
\text { Delayed }\end{array}$ & $\begin{array}{l}\text { Days Loco } \\
\text { delayed in } \\
\text { excess of } \\
\text { delay on } \\
\text { account of } \\
\text { Block }\end{array}$ \\
\hline $\mathrm{a}$ & $\mathrm{b}$ & $\mathrm{C}$ & d & $\begin{array}{l}\text { e (working } \\
\text { days from c } \\
\text { to d) }\end{array}$ & $f=(e-18)$ & $\begin{array}{l}\mathrm{g}= \\
\text { column h } \\
\text { Table 1 }\end{array}$ & $\begin{array}{l}\mathrm{h}=(\mathrm{g}-\mathrm{f}) \text { write } \\
0 \text { when }(\mathrm{g}-\mathrm{f}) \text { is } \\
\text { negative }\end{array}$ \\
\hline 1 & 14682 & 10.01 .2012 & 07.02 .2012 & 20 & 2 & 4 & 2 \\
\hline 2 & 18708 & 17.01.2012 & 13.02 .2012 & 24 & 6 & 2 & 0 \\
\hline 3 & 17772 & 31.01 .2012 & 12.03 .2012 & 33 & 15 & 12 & 0 \\
\hline 4 & 18659 & 03.02 .2012 & 05.03 .2012 & 26 & 8 & 11 & 3 \\
\hline 5 & 13189 & 28.02 .2012 & 23.03 .2012 & 20 & 2 & 5 & 3 \\
\hline 6 & 16104 & 19.032012 & 10.04 .2012 & 17 & 0 & 0 & 0 \\
\hline 7 & 18717 & 04.04 .2012 & 27.04 .2012 & 19 & 1 & 1 & 0 \\
\hline 8 & 14880 & 10.04 .2012 & 06.05 .2012 & 23 & 5 & 2 & 0 \\
\hline 9 & 14096 & 26.04 .2012 & 18.05 .2012 & 20 & 2 & 8 & 6 \\
\hline 10 & 16135 & 04.05 .2012 & 05.06 .2012 & 27 & 9 & 6 & 0 \\
\hline 11 & 16083 & 10.05 .2012 & 14.06 .2012 & 30 & 12 & 11 & 0 \\
\hline 12 & 14903 & 25.05 .2012 & 29.06 .2012 & 31 & 13 & 11 & 0 \\
\hline 13 & 16027 & 11.06 .2012 & 07.07 .2012 & 24 & 6 & 7 & 1 \\
\hline 14 & 14121 & 21.06 .2012 & 18.07 .2012 & 24 & 6 & 5 & 0 \\
\hline
\end{tabular}

\subsection{Cycle time of $\mathrm{POH}$ using Unit Replacement method in Engine section.}

Now the effect of applying "Unit Replacement" in the engine section on total cycle time will be calculated. It is assumed that one spare engine block assembly (unit) is available on $1^{\text {st }}$ January 2012 . The tentative date of completion of total cycle time $\mathrm{POH}$ using unit replacement method is calculated and recorded in Table 4 for the same 14 locos. 
Reduction of the time required for POH of Diesel Locomotives using Unit Replacement

\begin{tabular}{|c|c|c|c|c|c|c|c|c|c|}
\hline \multicolumn{10}{|c|}{ Table4.Cycle time for POH using unit replacement method } \\
\hline Sis & $\begin{array}{l}\text { Loco } \\
\text { Na }\end{array}$ & $\begin{array}{l}\text { Token in } \\
\text { hand date }\end{array}$ & $\begin{array}{l}\text { Dlock } \\
\text { Required } \\
\text { on Date } \\
\text { (18t day) }\end{array}$ & $\begin{array}{l}\text { Engine } \\
\text { Block } \\
\text { Reudy on } \\
\text { Date }\end{array}$ & $\begin{array}{l}\text { Is spare } \\
\text { block } \\
\text { (unit) } \\
\text { arailabie }\end{array}$ & $\begin{array}{l}\text { Date of } \\
\text { Waich LNIT } \\
\text { a availuble }\end{array}$ & $\begin{array}{l}\text { Tentative date of fipes } \\
\text { diapucht uaisgunit } \\
\text { seplacement }\end{array}$ & $\begin{array}{l}\text { Tentative } \\
\text { dayloco } \\
\text { can be } \\
\text { dispatched }\end{array}$ & Remariks \\
\hline a & $b$ & $\circ$ & $d$ & $E$ & 1 & 8 & h & 1 & 1 \\
\hline 1 & 14682 & 1001.12 & 31.01 .12 & 070212 & Yes & 0101.12 & 10.02 .12 & 27 & 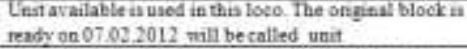 \\
\hline 2 & 15708 & 170112 & 07.0212 & 13.0212 & YES & 07.02 .12 & 1502.12 & 25 & $\begin{array}{l}\text { block of loce } 18708 \text { in reatly on } 1302: 2012 \text { it will be } \\
\text { the ueit }\end{array}$ \\
\hline 3 & 17772 & 31.01 .12 & 21.02 .12 & 12.0312 & YES & $13.02: 12$ & 22.02 .12 & 25 & $\begin{array}{l}\text { The block of loco } 17772 \text { is resdy on } 12.03 .2012 \text { it will } \\
\text { be the unit }\end{array}$ \\
\hline 4 & 15659 & 030212 & 24.02 .12 & 05.03 .12 & so & 12.03 .12 & 17.03 .12 & 36 & $\begin{array}{l}\text { Loeo delayed because wait was not avallable set } \\
\text { reason in the antysis }\end{array}$ \\
\hline 5 & 13189 & 280212 & 20.03 .12 & 23.03 .12 & YES & 1203.12 & 310312 & 28 & Biock of loco 13189 is seasty on 23.03 .12 is the unit \\
\hline 6 & 16104 & 190.12 & 10.04 .12 & 10,0412 & $\begin{array}{l}\text { NO } \\
\text { NEED }\end{array}$ & 2303.12 & 1004.12 & 25 & \\
\hline 7 & 18717 & 040412 & 26.04 .12 & 2704.12 & YES & 23.03 .12 & 04.05 .12 & 25 & $\begin{array}{l}\text { the block of loco } 18717 \text { is ready on } 27.042012 \text { it will } \\
\text { be the unit }\end{array}$ \\
\hline 8 & 14880 & 10.04 .12 & 30.04 .12 & 0005.12 & VES & 2704.12 & 0503.12 & 25 & $\begin{array}{l}\text { The block of loca } 14580 \text { is ready on } 06.05 .12 \text { it well be } \\
\text { the unit }\end{array}$ \\
\hline 9 & $1+096$ & 26.04 .12 & 16.05 .12 & 18.05 .12 & YES & 06.05 .12 & 3105.12 & 31 & $\begin{array}{l}\text { the block ofloto } 14096 \text { infeally on } 18,05,2012 \text { it will } \\
\text { be the unit }\end{array}$ \\
\hline 10 & 16135 & 0405.12 & 24.05 .12 & 05.0612 & YES & 1805.12 & 26.05 .12 & 25 & $\begin{array}{l}\text { the block of } 606016135 \text { is ready on } 05662012 \mathrm{stwat} \\
\text { be the unit }\end{array}$ \\
\hline II & 16083 & 100512 & 30.05 .12 & $1+66.12$ & VES & 0506.12 & 130612 & 29 & $\begin{array}{l}\text { the block of } 106016083 \text { isteady on } 14.062012 \mathrm{M} \text { will } \\
\text { be the unit }\end{array}$ \\
\hline 12 & 14903 & 25.03 .12 & 14.06 .12 & 290612 & YES & 140612 & 22.06 .12 & 25 & $\begin{array}{l}\text { the block of hoco } 14903 \text { is ready on } 29.062012 \text { it wall } \\
\text { be the usit }\end{array}$ \\
\hline 13 & 16027 & 150612 & 30.06 .12 & 0707.12 & YES & 29.0612 & 0907.12 & 26 & $\begin{array}{l}\text { the botok oflote } 16027 \text { isteady on } 07.07 .12 \text { if wall to } \\
\text { the unit }\end{array}$ \\
\hline 14 & 14121 & 210612 & 11.07 .12 & 180712 & YES & 07.07 .12 & 1607.12 & 25 & $\begin{array}{l}\text { the block of loco } 14121 \text { isteady on } 18.07 .12 \text { it wall be } \\
\text { the unit }\end{array}$ \\
\hline
\end{tabular}

3.5 results

From Table 4 it is clear that

a) Using unit replacement method 8 locos out of 14 can be turned out in the specified cycle time of 25 days.

b) Reduction in cycle time for $\mathrm{POH}$ is noticed in 5 locos.

c) There is no change in cycle time for loco number 18659 because unit for replacement is not available.

Why unit was not available?

Engine block for loco 17772 had cam eye bore oversized. Reclamation of the block having this type of excessive repair involves boring of cam eye bore, making oversized sleeve this takes time. In this particular loco block reclamation took extraordinary time otherwise chances of non availability of unit are rare.

\subsection{Comparison}

The comparison of cycle time $\mathrm{POH}$ with and without unit replacement is shown in Table 5. Total working days taken for $\mathrm{POH}$ of 14 locos under observation using existing method are 435 days. (As per column f of Table 5)

Average time taken per loco using existing method

;Average time $=\frac{\text { Total Days taken }}{\text { Total Locos over hauled }}$

;Average time $=\frac{435}{14}=31.07$ days

Total working days required for $\mathrm{POH}$ of same locos using unit replacement method is expected to be 377 days (as per column $\mathrm{g}$ of table 5)

Average time per loco using unit replacement

; Average time $=\frac{\text { Total Days calculated }}{\text { Total Locos over hauled }}$

; Average time $=\frac{377}{14}=26.92$ days

From the above observations it is clear that the average time required per loco using unit replacement method is expected to be 26.92 days, whereas, that using existing method is 31.07 days this support the hypotheses - Time required for Periodic Overhauling of Diesel Locomotives can be reduced using "Unit Replacement"

\subsection{Percentage savings.}

Percentage Saving $=\frac{\text { Total Days saved }}{\text { Total days taken }} * 100$

Percentage Saving $=\frac{58}{435} * 100$

Percentage Saving $=13.33 \%$ 


\subsection{Cost analysis:}

Application of the unit replacement method in engine section needs one spare engine block assembly costing about 15 million rupees, resulting additional work in process inventory worth rupees 15 million. Increase of this work in process inventory can be justified because-

- It is needed only once.

- The POH cycle time is reduced @ four days per loco resulting in savings of more than 100 loco days per annum.

- 100 loco days mean earnings of rupees 10 million because loco earns approximately Rs 100000/- per day when it rolls on the track with the load.

- Therefore, this additional cost of inventory can be recovered in 15 to 18 months and the additional engine block assembly will be available forever.

Table 5 Comparison of Cycle time $\mathrm{POH}$ with and without unit replacement

\begin{tabular}{|l|l|l|l|l|l|l|l|}
\hline $\begin{array}{l}\text { S. } \\
\text { No. }\end{array}$ & $\begin{array}{l}\text { Loco } \\
\text { No. }\end{array}$ & $\begin{array}{l}\text { Arrived } \\
\text { in shop } \\
\text { date }\end{array}$ & $\begin{array}{l}\text { Taken in } \\
\text { hand } \\
\text { date }\end{array}$ & $\begin{array}{l}\text { Dispatch } \\
\text { Date }\end{array}$ & $\begin{array}{l}\text { Working } \\
\text { days using } \\
\text { existing } \\
\text { method } \\
\text { (From } \\
\text { column g } \\
\text { of Table 1) }\end{array}$ & $\begin{array}{l}\text { Tentative } \\
\text { working } \\
\text { Days on } \\
\text { which the } \\
\text { loco can be } \\
\text { dispatched } \\
\text { as per } \\
\text { column i } \\
\text { of Table 4 }\end{array}$ & $\begin{array}{l}\text { Days } \\
\text { Saved }\end{array}$ \\
& & & & & & g & h=(f-g) \\
\hline a & b & c & d & e & f & 27 & 2 \\
\hline 1 & 14682 & 09.01 .12 & 10.01 .12 & 13.02 .12 & 29 & 27 & 2 \\
\hline 2 & 18708 & 14.01 .12 & 17.01 .12 & 17.02 .12 & 27 & 25 & 12 \\
\hline 3 & 17772 & 30.01 .12 & 31.01 .12 & 15.03 .12 & 37 & 25 & 0 \\
\hline 4 & 18659 & 31.01 .12 & 03.02 .12 & 17.03 .12 & 36 & 36 & 2 \\
\hline 5 & 13189 & 27.02 .12 & 28.02 .12 & 03.04 .12 & 30 & 28 & 2 \\
\hline 6 & 16104 & 17.03 .12 & 19.03 .12 & 19.04 .12 & 25 & 25 & 0 \\
\hline 7 & 18717 & 03.04 .12 & 04.04 .12 & 05.05 .12 & 26 & 25 & 1 \\
\hline 8 & 14880 & 07.04 .12 & 10.04 .12 & 11.05 .12 & 27 & 25 & 2 \\
\hline 9 & 14096 & 25.04 .12 & 26.04 .12 & 02.06 .12 & 33 & 31 & 2 \\
\hline 10 & 16135 & 03.05 .12 & 04.05 .12 & 08.06 .12 & 31 & 25 & 6 \\
\hline 11 & 16083 & 05.05 .12 & 10.05 .12 & 20.06 .12 & 36 & 29 & 7 \\
\hline 12 & 14903 & 24.05 .12 & 25.05 .12 & 05.07 .12 & 36 & 25 & 11 \\
\hline 13 & 16027 & 08.06 .12 & 11.06 .12 & 17.07 .12 & 32 & 26 & 6 \\
\hline 14 & 14121 & 20.06 .12 & 21.06 .12 & 25.07 .12 & 30 & 25 & 5 \\
\hline TOTAL & & & & & 435 & 377 & 58 \\
\hline
\end{tabular}

\section{Conclusion}

The results of unit replacement support the hypothesis that the time required for $\mathrm{POH}$ of diesel locomotive can be reduced using unit replacement method. Applying unit replacement method only in one section of diesel shop has shown reduction in average cycle time of POH from 31.07 days to 26.92 days resulting in saving of nearly 4 days per loco and annually more than 100 loco days can be saved.

Periodic Overhauling of diesel locomotive includes a large number of maintenance operations dealing with thousands of different components. A variety of problems are also associated with this maintenance schedule. Each loco has a different problem. These problems can be solved by replacing the unit.

"Unit Replacement" method may also overcome some other reason of delay say more workers on leave due to a festive season, non availability of a critical component, excessive repair work in one or more component, power failure for a specific period etc.

Unit replacement does not cover the problems related to the chassis of loco because the chassis of loco cannot be replaced.

Although the data supports the hypotheses yet experiments on actual basis needs to take place before the hypotheses is confirmed 


\section{ACKNOWLEDGEMENTS}

The authors are greatly thankful to Dy. Chief Mechanical Engineer Loco Workshop Ajmer who granted the permission to carry out a study at Loco Workshop Ajmer.

The authors would also like to thank Senior Section Engineers working at different sections in Diesel Shop Ajmer who helped to collect all relevant data and informations required for this project. Without their cooperation it would not be possible to do this work.

\section{References}

[1] Vorster, Hendrik Petrus De Wet, "An analysis of the effectiveness of the asset maintenance plan at Spoornet: case study: class diesel locomotives (traction and rolling stock)" (2001). Peninsula Technikon Theses \& Dissertations. Paper 14. http://dk.cput.ac.za/td_ptech/14

[2] Kaiser, Kevin Michael University of Iowa, 2007. http://ir.uiowa.edu/etd/152

[3] Harris, A and Kelly, M. 1978 Management of Industrial Maintenance. Durban, South Africa: Butterworth \& Co (Pty) Ltd.

[4] Seventeenth Report Standing Committee on Railways (2005-06) (Fourteenth Lok Sabha) Ministry of railways (Railway board) Published under Rule 382 of the Rules of Procedure and Conduct of Business in Lok Sabha (Eleventh Edition) and Printed by Jainco Art India, New Delhi-110 005. 